\title{
The laboratory diagnosis of sexually transmitted infections in cases of sexual assault and abuse
}

\author{
Max A Chernesky PhD, Colin Hewitt BSc ART
}

\begin{abstract}
MA Chernesky, C Hewitt. The laboratory diagnosis of sexually transmitted infections in cases of sexual assault and abuse. Can J Infect Dis Med Microbiol 2005;16(2):63-64.

Laboratory staff dealing with samples from victims must be aware that such patients have been psychologically traumatized and deserve special care. The help of a sexual assault care team should be sought if available, and appropriate specimens should be collected two to 10 days after an incident, preferably in a single visit. Specimens should be clearly labelled, and the laboratory should be informed. In the laboratory, all procedures need to be clearly documented. There are special requirements for the collection of forensic specimens and associated records, which may later be required for legal proceedings. The laboratory must know what the current legal status is for any test being used in that community. The present article serves as a guideline to more detailed practice standards for the investigation of individual sexually transmitted infections in assault and abuse situations.
\end{abstract}

Key Words: Abuse; Assault; Canada; Forensics; Laboratory; Legal issues; Trauma

A laboratory investigation of sexual assault or abuse requires the collection of appropriate specimens from the victim and, if possible, the alleged perpetrator. Guidelines for physicians and nurses on the evaluation, documentation, investigation and management of victims of sexual assault or abuse are published in the 'Canadian STD Guidelines' (1) and in the textbook Sexually Transmitted Diseases (2).

In all cases, the clinician should examine the patient for evidence of abuse or assault and submit specimens to the laboratory according to signs or symptoms, the prevalence of a sexually transmitted infection (STI) in the community, information regarding the medical condition of the alleged perpetrator if known, and a history of oral, genital or rectal sexual contact.

There are legal obligations on health care providers to report suspected child sexual abuse to the appropriate authorities. Also, any finding of a reportable disease must be communicated to the local public health authorities. It should be noted that in some instances, the presence of an STI in a child may be the result of neonatal or other exposure.

\section{SPECIMEN COLLECTION AND TESTING}

Victims will likely be suffering both physical and psychological trauma; thus, the health care workers who interact with them must be sensitive to their condition and needs. Many

\section{Analyses de laboratoire et MTS dans les cas d'abus sexuel}

Le personnel des laboratoires qui doit manipuler des échantillons provenant de victimes d'abus sexuels doit savoir que ces patients ont été psychologiquement traumatisés et qu'ils méritent une attention particulière. L'aide d'une équipe spécialisée doit être recherchée, le cas échéant, et les spécimens appropriés doivent être recueillis dans les deux à dix jours qui suivent un incident, préférablement en une seule séance. Les spécimens doivent être clairement identifiés et le laboratoire doit être informé de la situation. Au laboratoire même, toutes les procédures doivent être clairement documentées. Il existe des directives particulières pour la collecte des spécimens en médecine légale et pour la tenue des dossiers qui s'y rattachent puisqu'ils peuvent éventuellement être fournis comme éléments de preuve lors de procédures judiciaires. Le laboratoire doit connaître le statut légal des tests utilisés dans la communauté. Le présent article peut servir de ligne directrice sur les normes de pratique appliquées au dépistage des infections transmises lors de la perpétration de crimes de nature sexuelle. communities have sexual assault care centres in local hospitals or clinics, staffed by a team specially trained to handle such patients; these services should be employed. Appropriate specimens should be obtained from the victim during a single visit to minimize psychological trauma to the patient. Specimens for STI diagnosis should be collected two to 10 days after an incident of sexual assault; specimens collected earlier may yield false-negative results. All specimens must be clearly labelled with the patient's name and the site of collection. The laboratory must be alerted that the specimens are from a person suspected to have been sexually abused and/or assaulted.

In the laboratory, all procedures must be precisely documented and adhere to the laboratory's written standard operating procedures. In case additional testing is needed later by legal authorities, specimens and isolates may need to be stored separately and for longer than is the routine.

In most cases, the health care provider collecting the specimens for STI testing will also be collecting any specimens from the patient for forensic testing. Forensic samples for DNA, such as oral, vaginal or rectal swabs, are taken before taking samples for STI testing. It is important to collect these specimens correctly so that neither avenue of testing is compromised. For example, genital specimens from the victim for forensic DNA testing could be compromised if a 
urine specimen for STI testing is collected first. Forensic testing is normally performed in cooperation with the local police authorities (1).

\section{Cervical swabs}

Endocervical swabs are collected and submitted only from pubertal and adult females. In prepubertal females, a vaginal swab is taken. The swab should be transported in a tube appropriate for the assay that is used. For medicolegal purposes, cervical swabs should be cultured for Neisseria gonorrhoeae and Chlamydia trachomatis. Nucleic acid amplification (NAA) tests, such as polymerase chain reaction, strand displacement amplification or transcription-mediated amplification, may also be performed. Positive results should be confirmed by a second assay, different from the first. Other nonculture assays should not be used because they are not acceptable for medicolegal purposes.

\section{Anal canal}

Anal specimens should be submitted for $N$ gonorrhoeae and $\mathrm{C}$ trachomatis as indicated above for cervical swabs. At the time of writing, none of the commercial NAA tests are approved for anal swabs, but confirmed positive results may aid the investigation.

\section{Pharynx}

The above guidelines for anal samples apply to pharyngeal swabs.

\section{Urethral swabs}

Although urethral swabs may be collected from teenage and adult males, collection in prepubertal children is too difficult and painful. Therefore, a meatal swab should be collected from the prepubertal child and submitted to the laboratory to be cultured and processed for NAA testing as indicated above for cervical swabs.

\section{Urine}

A sample of urine (the first void or first catch represented by the first $20 \mathrm{~mL}$ of any micturition) is an excellent specimen from either sex for $\mathrm{C}$ trachomatis and $\mathrm{N}$ gonorrhoeae testing by NAA. The urine may also be used to look for Trichomonas vaginalis by wet mount and culture.

\section{Vaginal swab}

Vaginal samples collected without a speculum can be effective for $\mathrm{C}$ trachomatis and $\mathrm{N}$ gonorrhoeae testing by NAA. Cultures should also be set up. Additional investigations may include culture for herpes simplex virus (HSV) and culture or wet mount for $T$ vaginalis; these are requested based on the clinical findings at the time of specimen collection.

\section{Genital ulcers}

Genital ulcer material should be set up for the culture of HSV and Haemophilus ducreyi. This material may also be tested by polymerase chain reaction for HSV, $\mathrm{H}$ ducreyi and Treponema pallidum.

\section{Sera}

Antibody tests may be useful for HIV, hepatitis B virus and syphilis. Sexual assault care centres may not recommend testing for HIV during the acute time frame following an assault because most victims are too psychologically distressed to understand HIV counselling and the implications of the test results. The exception to this is when the victim requests or decides to accept HIV prophylaxis, which many sexual assault care centres offer at this time. In this case, a baseline test allows the health care provider to determine whether prophylaxis or treatment is being provided. In any event, a serum specimen should be collected at this first visit and stored frozen so that it is available if a victim later opts to be tested for HIV or if other additional testing is required. Repeat serology should be offered at approximately 12 weeks and 24 weeks after an acute assault. If a victim has a positive test result at the 12 or 24 week follow-up, testing of the baseline blood sample will help to determine if the infection was possibly transmitted during the assault, or was pre-existing.

While the sexual transmission of hepatitis $\mathrm{C}$ virus is uncommon, it does occur; thus, hepatitis $\mathrm{C}$ virus testing may be requested.

\section{REFERENCES}

1. LCDC Expert Working Group on Canadian Guidelines for Sexually Transmitted Diseases. Canadian STD Guidelines, 1998 edition. <http://www.phac-aspc.gc.ca/publicat/std-mts98/pdf/std98_e.pdf> (Version current at January 27, 2005).

2. Holmes KK, Sparling PF, Mardh P-A, et al. Sexually Transmitted Diseases, 3rd edn. New York: McGraw-Hill Professional, 1998. 


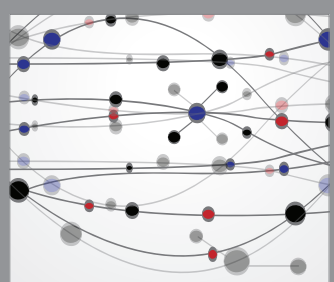

The Scientific World Journal
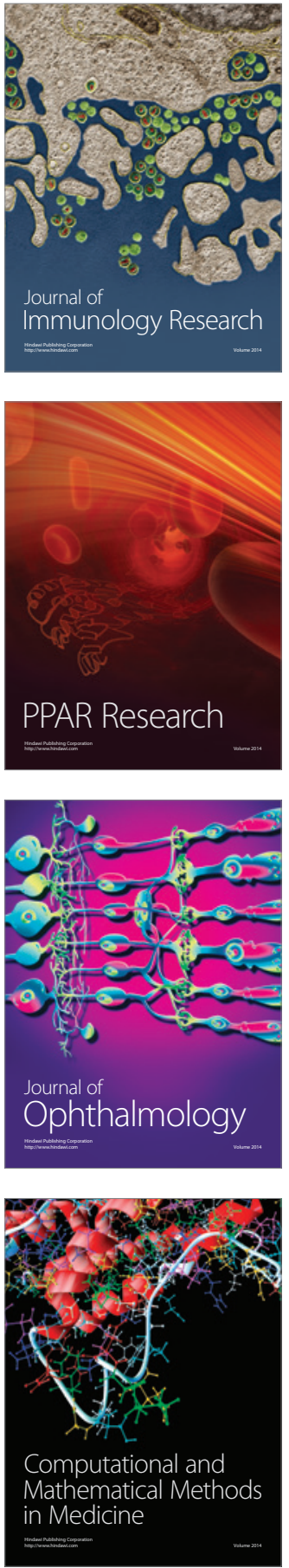

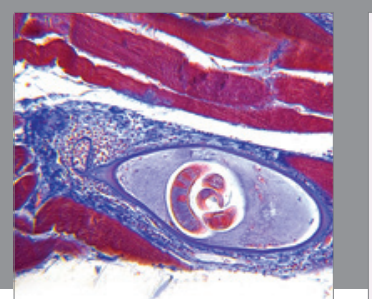

Gastroenterology Research and Practice

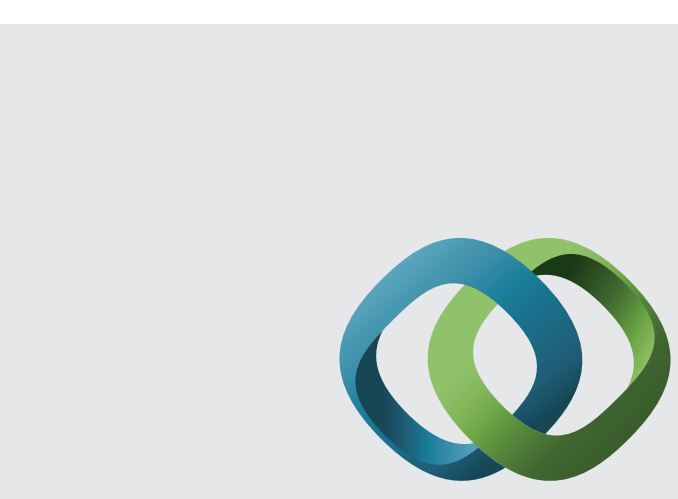

\section{Hindawi}

Submit your manuscripts at

http://www.hindawi.com
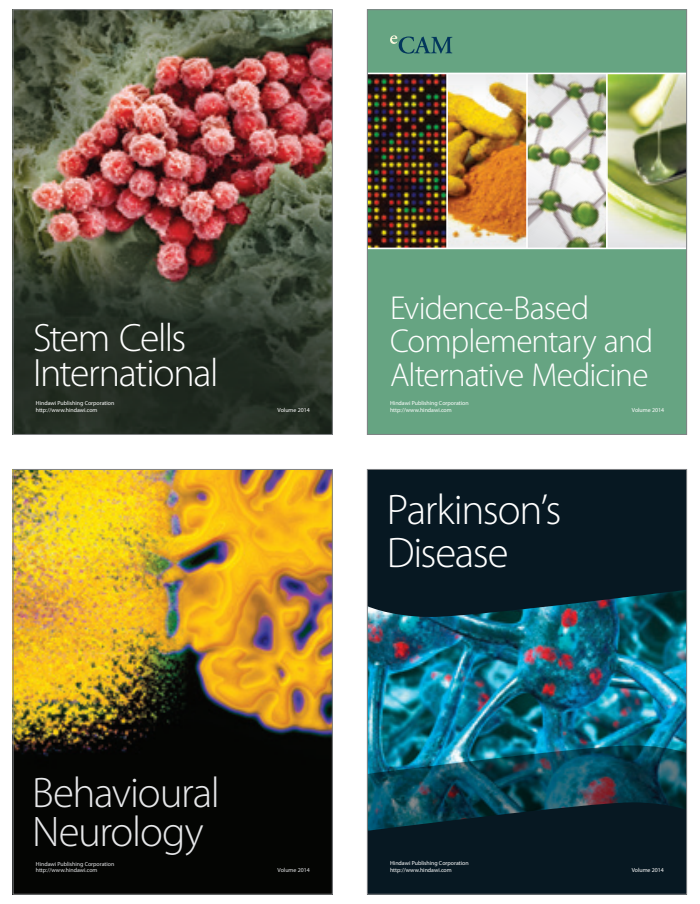
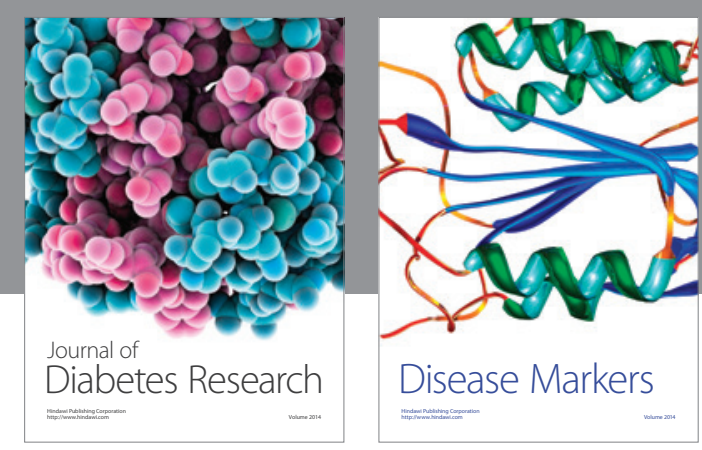

Disease Markers
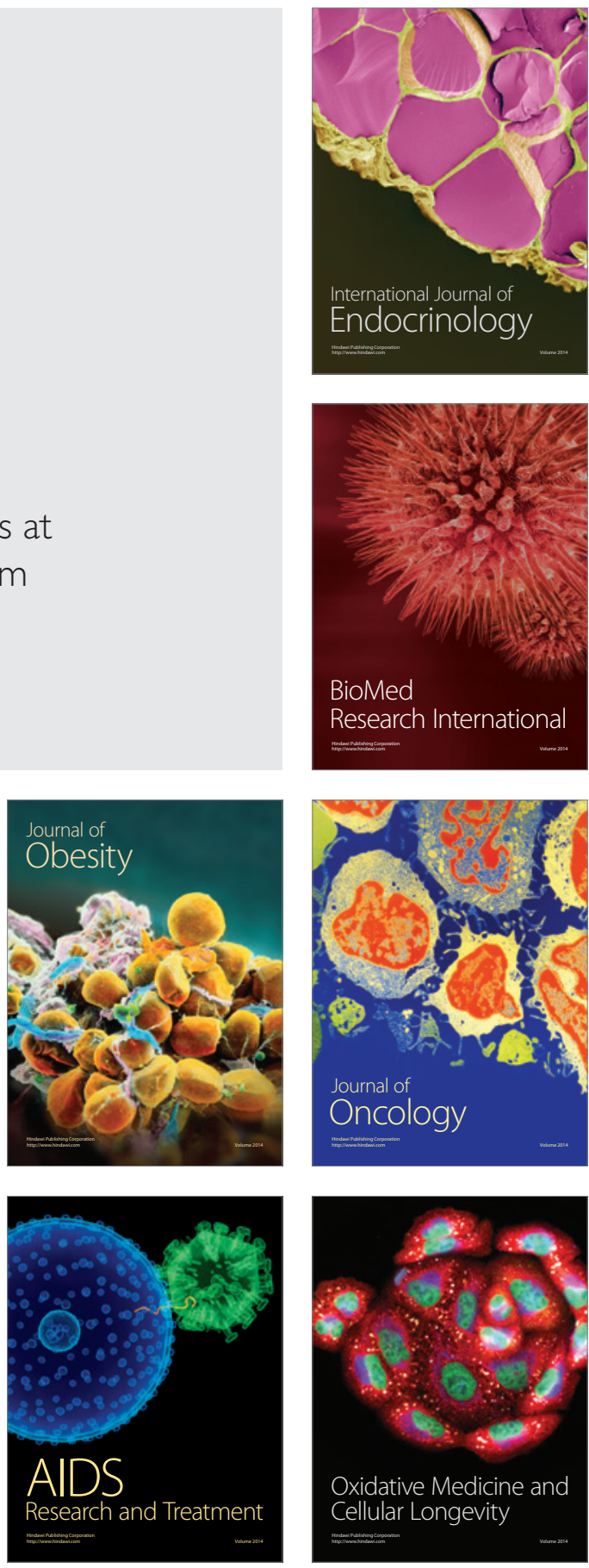